\title{
Preservative solutions on quality and biochemical aspects of calla lily flowers
}

\section{Soluções preservativas na qualidade e aspectos bioquímicos de flores de copo-de-leite}

\author{
Thais Silva Sales ${ }^{1}$, Patrícia Duarte Oliveira Paiva ${ }^{2 *}$, Heloísa Helena de Siqueira ${ }^{3}$, \\ Guilherme Mariano Manfredini², Luiz Carlos de Oliveira Lima ${ }^{3}$
}

\author{
${ }^{1}$ Universidade Federal dos Vales do Jequitinhonha e Mucuri/UFVJM, Diamantina, MG, Brasil \\ ¿Universidade Federal de Lavras/UFLA, Departamento de Agricultura/DAG, Lavras, MG, Brasil \\ ${ }^{3}$ Universidade Federal de Lavras/UFLA, Departamento de Ciencia dos Alimentos/DCA, Lavras, MG, Brasil \\ *Corresponding author: patriciapaiva@dag.ufla.br
}

Received in July 27, 2017 and approved in November 16, 2017

\begin{abstract}
The knowledge of physiological and biochemical aspects occurring at the postharvest phase of flowers is critical to guide efficient conservation techniques for maintaining quality and longevity. Factors that cause deterioration of cut flowers after harvest are dehydration, low carbohydrate contents, the presence of microorganisms in vase solution or stem and late stage of development at harvest. Thus, the objective was to determine the effect of harvest stages of calla lily stems and storage solutions on water relations and contents of starch and sugars. Flower stems were harvested in the following opening stages of the spathe: early-stage (cartridge) and $1 / 3$ open and were arranged in six storage solutions containing 1, 2, 4 and $6 \%$ glucose and the controls with water and solution with $5 \%$ sucrose. Results indicate that at early-stage and $1 / 3$ open harvesting stages, the addition of glucose at concentrations of $4 \%$ and $6 \%$ stimulated flower opening. Calla lily flower stems maintained in water and in solution with $1 \%$ glucose had lower percentages of fresh weight loss and better maintenance of water balance, with a small reduction in the contents of starch and soluble sugars. The addition of sugars in the storage solution was efficient in opening early-harvested stems. Harvest the floral stems in initial stages allow the maintenance of the commercial quality for longer period, without pollen production. The use of water relations allowed the determination of the better sugar concentration for the conservation of open-harvest of floral stems.
\end{abstract}

Index terms: Zantedeschia aethiopica; storage solutions; glucose; cut flowers; water relation.

\section{RESUMO}

O conhecimento de aspectos fisiológicos e bioquímicos ocorrentes na etapa pós-colheita de flores é fundamental para nortear a realização de técnicas eficientes de conservação para manutenção de qualidade e durabilidade. Entre os fatores que causam deterioração de flores cortadas após a colheita consideram-se a desidratação, baixos teores de carboidratos, presença de microrganismos e o estágio de desenvolvimento no momento da colheita. Assim, objetivou-se determinar as relações hídricas, os teores de amido e açúcares solúveis totais em função dos estádios de colheita e diferentes soluções de manutenção utilizadas para hastes de copo-de-leite. As hastes florais foram colhidas nos estádios de abertura da espata: fechada (cartucho) e 1/3 aberta e dispostas em seis soluções conservantes: 1, 2, 4 e $6 \%$ de glicose e os controles água e solução com $5 \%$ de sacarose. Tanto para o estádio de colheita fechado quanto para $1 / 3$ aberto, a adição, respectivamente, de glicose nas concentrações $4 \%$ e $6 \%$, estimulou a abertura floral. As hastes florais de copo-de-leite mantidas em água e em solução com 1\% de glicose apresentaram menor porcentagem de perda de massa fresca e melhor manutenção do balanço hídrico, com pequena redução dos teores de amido e açúcares solúveis. A adição de açúcares na solução conservante foi eficiente na promoção da abertura de hastes colhidas precocemente. A colheita em estádios iniciais de abertura permite a manutenção da qualidade comercial por maior período, sem a produção de pólen. Por meio da análise de relações hídricas foi possível determinar melhor concentração de açúcares de solução conservante para hastes florais colhidas abertas.

Termos para indexação: Zantedeschia aethiopica; soluções conservantes; glicose; flores de corte; relações hídricas.

\section{INTRODUCTION}

The flower developmental stage at harvest, dehydration, exhaustion of carbohydrates, the presence of microorganisms in stem, exposure to inappropriate temperatures and are the main factors influencing senescence in cut flowers (Nowak; Rudnicki, 1990, Almeida et al., 2017).

In order to delay senescence, the application of exogenous carbohydrate sources in the storage solution provides energy for the maintenance of respiration during the opening of flower buds, reduction of transpiration, 
and control of the stomatal closure and osmotic tissue regulation (Schmitt et al., 2013).

Therefore, for the composition of a flower storage solution, various sugars such as sucrose, glucose, fructose or trehalose may be used (Reid; Jiang, 2012). Among them, sucrose is the carbohydrate mostly used in conditioning solutions (Nowak et al., 1991). The optimal sucrose concentration depends on the species, variety or the flower stem developmental stage (Nowak; Rudnicki, 1990). For example, in lily inflorescences, the use of 5\% sucrose in the conditioning solution allowed the harvest of inflorescences at earlier stages, enabling flower bud opening and longer pot life (Barbosa et al., 2005). The use of pulsing with sucrose is effective to extend calla lily opening and longevity (Almeida et al., 2008; 2011), as well as bird-of-paradise (Bayogan; Jaroenkit; Paull, 2008), Agapanthus praecox (Burge et al., 2010) and Bougainvillea glabra (Moneruzzaman et al., 2010).

Besides conservation, the control of flower bud opening, percentage of stems with inclined tip and petal coloration was favored by the use of $6 \%$ sucrose or glucose in Eustoma grandiflorum (Cho; Celikel; Dodge, 2001). On the other hand, the use of glucose in storage solution was more effective, when compared to sucrose, for floral bud opening and pot life of Dendrobium 'Youppadeewan' (Ketsa; Boonrote, 1990). The fresh weight and longevity of tulips were favored by the use of $1 \%$ glucose in storage solution (Watanabe et al., 2013).

Carbohydrate accumulation can also favor water balance. Sucrose accumulated in flowers increases the concentration of osmotically active solutes, leads to water absorption and, therefore, the maintenance of petal turgor (Halevy, 1976) and maintenance of flower opening (Costa; Finger, 2016). Moreover, sucrose acts in stomatal closure and reduces water loss in cut flowers (Van Doorn, 2001).

The carbon reserve in the stem is used to extend the potential flower longevity (Kays, 1991); therefore, cut flowers with higher carbohydrate concentrations have a higher postharvest longevity (Nowak; Rudnicki, 1990; Marissen, 2001).

In this context, the objective was to determine the effect of harvest stages of calla lily stems and storage solutions on water relations and contents of starch and sugars.

\section{MATERIAL AND METHODS}

\section{Plant Material}

Calla lily (Zantedeschia aethiopica) flower stems were collected in the morning, at the following opening stages of the spathe: early-stage (cartridge) and 1/3 open (Figure 1), according to Sales et al. (2015).

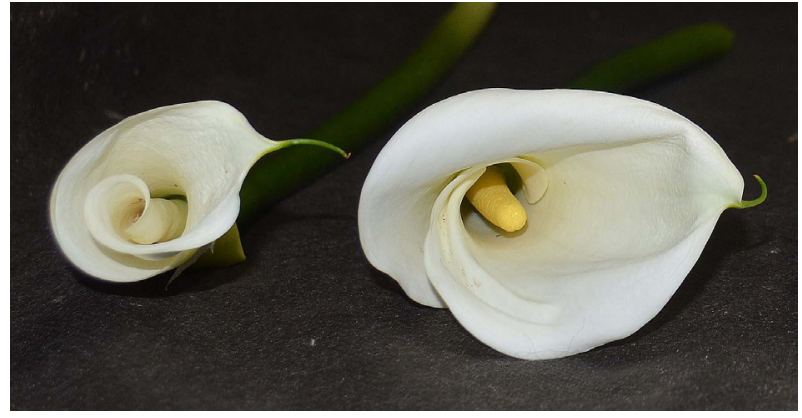

Figure 1: Harvest stages of calla lily flower stems: early-stage spathe (cartridge) and 1/3 open-right.

\section{Treatments}

The stems were transported dry, for one hour, to the laboratory, where they were immersed in water and kept at $21 \pm 2{ }^{\circ} \mathrm{C}$. Once selected and standardized at $50 \mathrm{~cm}$, the stems were weighed to determine fresh weight and subjected to the treatments. The experiment consisted of 12 treatments in a factorial arrangement with two harvest stages and six storage solutions with 1, 2, 4 and $6 \%$ of anhydrous glucose and two controls: double distilled water and a solution with $5 \%$ sucrose (according to Almeida et al., 2011). Each stem was placed on a plastic pot containing $0.5 \mathrm{~L}$ storage solution. Daily the solution was complete in order to maintain the final volume of $0.5 \mathrm{~L}$. The pots were sealed with a plastic bag around the stem to prevent water evaporation.

The flower stems were placed in a room at room temperature $\left(21 \pm 2{ }^{\circ} \mathrm{C}\right)$ and relative humidity of $75 \pm 5 \%$, for a period of $12 \mathrm{~d}$. Assessments of water $\mathrm{pH}$, presence of pollen, commercial quality, width and length of the spathe, fresh weight, water absorption and transpiration, were performed daily. For the soluble sugars and starch analyses, samples were collected every $2 \mathrm{~d}$.

The commercial quality of the stems was assessed according to the pattern determined by Almeida et al. (2008): class A1- turgid inflorescences, with inclined spathe tip and absence of roughness or necrosis; class A2 - turgid inflorescences, with the spathe tip slightly rolled down and absence of roughness or necrosis; class B - turgid inflorescences, with the spathe tip slightly rolled down, presence of roughness, absence of necrosis; class $\mathrm{C}$ - wilted inflorescences, with the spathe tip rolled down and presence of necrosis. This is a noncommercial inflorescences and the point for waste that.

From assessments of flower stem quality, is was determined that the sum of the days in which they remained in classes A1, A2 and B represent the pot life of these inflorescences; stems classified as A1 indicate the best quality, and those classified as $\mathrm{C}$ were considered as a waste. 


\section{Water relation}

The absorption rate was obtained by determining the volume of consumed water, in $\mathrm{mL} \mathrm{d}^{-1}$ evaluated per stem, and the transpiration rate was estimated in $\mathrm{g} \mathrm{d}^{-1}$ evaluated per stem, according to Sales et al. (2015): $\mathrm{T}=$ $\mathrm{V}_{\mathrm{c}}-\left(\mathrm{MH}_{\mathrm{f}}-\mathrm{MH}_{\mathrm{i}}\right)$, where $\mathrm{T}$ : transpiration rate $\left(\mathrm{g} \mathrm{d}^{-1}\right) ; \mathrm{V}_{\mathrm{c}}$ : consumed solution volume $(\mathrm{g}) ; \mathrm{MH}_{\mathrm{i}}$ : early stem weight (g); $\mathrm{MH}_{\mathrm{f}}$ : late stem weight (g).

Changes in fresh weight were determined by daily weighing of flower stems, and the value was determined according to Sales et al. (2015): VMF $=\left(M_{f} \times 100\right) / M_{i}$; where VMF: variation in fresh weight $(\%) ; M_{i}$ : stem fresh weight on the first day of evaluation $(\mathrm{g}) ; \mathrm{M}_{\mathrm{f}}$ : stem fresh weight on the day of evaluation $(\mathrm{g})$.

\section{Biochemistry studies}

For the content quantification of starch and soluble sugars, samples with $5.0 \mathrm{~g}$ spathe were used, and stored in a freezer at $-80^{\circ} \mathrm{C}$ until the time of analysis. Total soluble sugars were determined by the anthrone method (Dische, 1962). Starch extraction was performed with $70 \%$ ethanol and dosing was performed by the Somogy method, with adaptations performed by Nelson (1944). In both analyses, readings were taken in a spectrophotometer and the results were expressed as a percentage.

\section{Statistical design and analysis}

Three replicates and two stems per plot were used in a completely randomized design. The model used was split plot in time, in which opening stages and storage solutions were the plot and the days of evaluation, the subplot. The data obtained in the experiment were pooled and submitted to the Tukey test at $5 \%$ probability for qualitative data, and analyzed with the aid of the software R (R Development Core Team, 2006).

\section{RESULTS AND DISCUSSION}

\section{Postharvest quality}

The $\mathrm{pH}$ of the solution was determined during the experimental period and had three levels: glucose storage solutions ranged from 5.2 to 5.7 , the solution with sucrose was in the range of 6.0 to 6.5 , while water ranged between 7.0 and 7.5 . The optimal $\mathrm{pH}$ range recommended for cut flowers is 3 and 4 (Gast, 2000), which prevents bacterial proliferation and vascular occlusion, increasing water absorption and maintenance of stem turgor.
Assessing the number of days in which calla lily flower stems remained in classes A1, A1+A2 and $\mathrm{A} 1+\mathrm{A} 2+\mathrm{B}$, an effect was observed only for the harvest stages (Table 1), regardless of the storage solutions used. Flower stems harvested early remained longer in class A1 (7.6 d) and had increased longevity (10.1 d), while those $1 / 3$ open remained in class A1 $5.7 \mathrm{~d}$, with total longevity of $8.8 \mathrm{~d}$ (classes $\mathrm{A} 1+\mathrm{A} 2+\mathrm{B})$.

Table 1: Number of days in which calla lily flower stems remained in qualitative classes $A 1, A 1+A 2, A 1+A 2+B$, as a function of harvest stage, at $21 \pm 2{ }^{\circ} \mathrm{C}$.

\begin{tabular}{cccc}
\hline \multirow{2}{*}{$\begin{array}{c}\text { Harvest } \\
\text { stage }\end{array}$} & \multicolumn{3}{c}{ Days* } \\
\cline { 2 - 4 } & Class A1 & Class A1+A2 & Class A1+A2+B \\
\hline Early-stage & $7.6 \mathrm{a}$ & $7.7 \mathrm{a}$ & $10.1 \mathrm{a}$ \\
$1 / 3$ open & $5.7 \mathrm{~b}$ & $6.6 \mathrm{~b}$ & $8.8 \mathrm{~b}$ \\
\hline
\end{tabular}

*Averages followed by the same letter in columns do not differ by the Tukey test at $5 \%$ probability.

Flower stems harvested in early stage remained approximately 2 more days in class $\mathrm{A} 1$ and 1 more day in classes $\mathrm{A} 1+\mathrm{A} 2$ and $\mathrm{A} 1+\mathrm{A} 2+\mathrm{B}$, compared with flower stems harvested $1 / 3$ open. Increased longevity in earlyharvested flower stems was also observed in other species, such as lily (Barbosa et al., 2005). The harvest in earlystage of the floral stems can be a good alternative to more distant consumer markets, since quality is maintained for a longer period. Moreover, they decrease the difficulty in transportation, take up less space in vehicles, facilitate packaging and suffer less damage (Paiva; Almeida, 2012; Castro et al., 2014).

The harvest in early stage provided more days without the release of pollen, compared to $1 / 3$ open for all storage solutions tested (Figure 2).

For the stems early-harvested, glucose concentrations of $1 \%$ and $6 \%$ provided greater time without the presence of pollen, on average, 9 and $8 \mathrm{~d}$ after harvest. For stage $1 / 3$ open, despite the early release of pollen in solutions containing only water and 1\% glucose, inflorescences remained for more days in the absence of pollen, on average, 3.83 and 3.67 .

By the expansion of the spathe in width and length, it can be seen that the observed values changed with harvest point and storage solutions (Figures 3 and 4). The stage $1 / 3$ open showed greater expansion, compared to early-stage, reaching a maximum width of 10.4 and 6.3 $\mathrm{cm}$, respectively (Figure 3 ). 


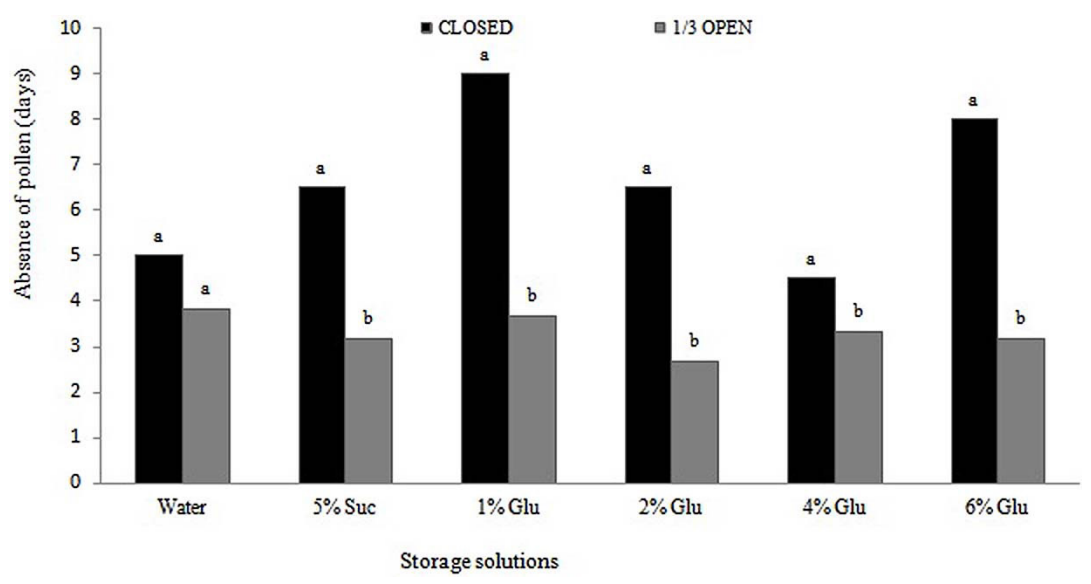

Figure 2: Number of days in which calla lily flower stems remained without the presence of pollen as a function of different harvest stages and storage solutions. Averages followed by the same letter for storage solution do not differ by the Tukey test at $5 \%$ probability.

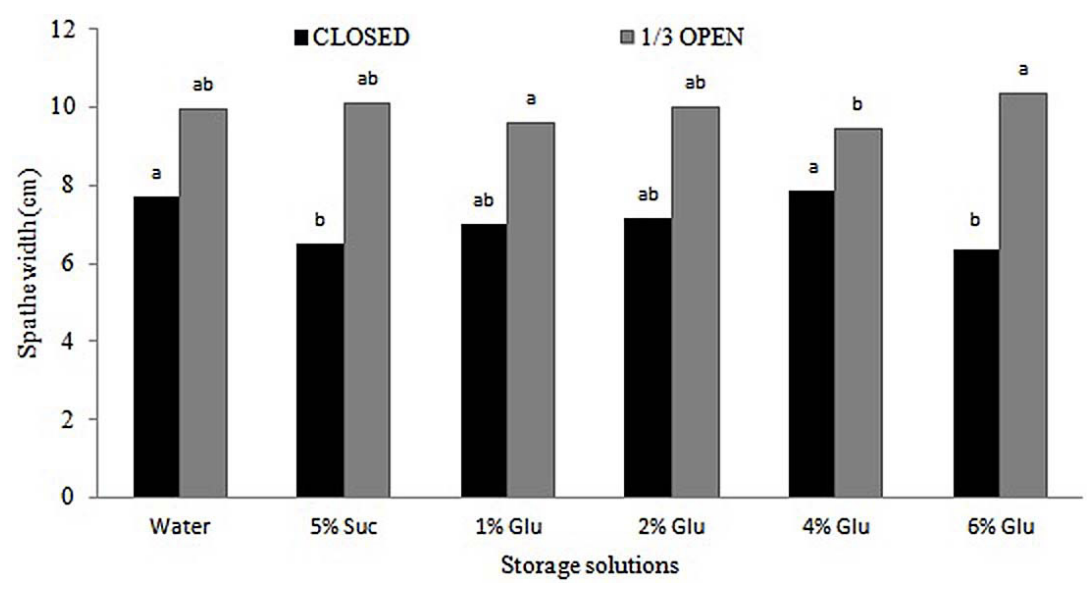

Figure 3: Spathe width of calla lily flower stems as a function of harvest stage and storage solutions. Averages followed by the same letter for harvest stage do not differ by the Tukey test at $5 \%$ probability.

The presence of pollen in the spadix is not desirable, once it reduces flower stem quality and indicates the loss of commercial value, besides causing a considerable acceleration in the signs of senescence in the spathe, such as wilting and abscission (Paiva; Almeida, 2012).

Stems harvested $1 / 3$ open and maintained in solution with $6 \%$ glucose had larger width, while the smallest width was observed in the solution with $4 \%$ glucose.

Analyzing spathe length, which indicates the opening and maturation of the inflorescence, it was influenced by harvest stage and storage solutions (Figure 4).

Flower stems harvested $1 / 3$ open had greater expansion, reaching a maximum length of $14.2 \mathrm{~cm}$, when placed in solution with $6 \%$ glucose (Figure 4). Early-harvest stems show maximum values of $11.80 \mathrm{~cm}$, when in solution with $4 \%$ glucose. Considering harvest $1 / 3$ open, the stems maintained in solution with $4 \%$ glucose showed the shortest length, while in early-harvest stems, the shortest length was observed in the solution with $6 \%$ glucose.

The largest spathe expansion was observed in stems harvested at stage $1 / 3$ open. This indicates that, since harvest time influences development, and thus, harvest in more advanced stages, the spathe can reach larger dimensions.

Regarding calla lily flower stems harvested in two early opening stages, both showed a reduction in fresh weight over the evaluation period (Figure 5). Stems harvested at stage $1 / 3$ open and early did not differ when maintained in water, with a fresh weight loss of $2.8 \%$ and $3.5 \%$, respectively. It 
was also found that stems kept in solution with $1 \%$ glucose showed no difference between harvest stages, but the smallest weight loss was observed for stage $1 / 3$ open $(2.3 \%)$, and early stages showed a loss of $3.2 \%$.

\section{Water relation}

Analyzing the absorption rate of water, it was higher in stems harvested $1 / 3$ open and, considering the storage solutions, the application of $1 \%$ glucose yielded higher absorption rates (Figure 6A). In stems kept in water, absorption rate was high, and there was no difference between harvest stages. In this condition, there was no difference in absorption rate, comparing flower stems harvested early or 1/3 open. There was no difference for stems kept in solution with sucrose.
Considering the use of glucose solution, a higher absorption was observed in stems harvested $1 / 3$ open, except for the solution with 4\% (Figure 6A). A similar behavior was observed for the analysis of transpiration rate (Figure 6B).

The addition of sugars in the storage solution was effective to induce the opening of early-harvested stems. Both for early-harvest and 1/3 open, the addition of glucose increased flower opening, as already observed for Eustoma grandiflorum (Cho; Celikel; Dodge, 2001). It was also observed that the use of glucose in storage solutions was more effective when compared to sucrose, with effects similar to those observed in Dendrobium 'Youppadeewan' (Ketsa; Boonrote, 1990).

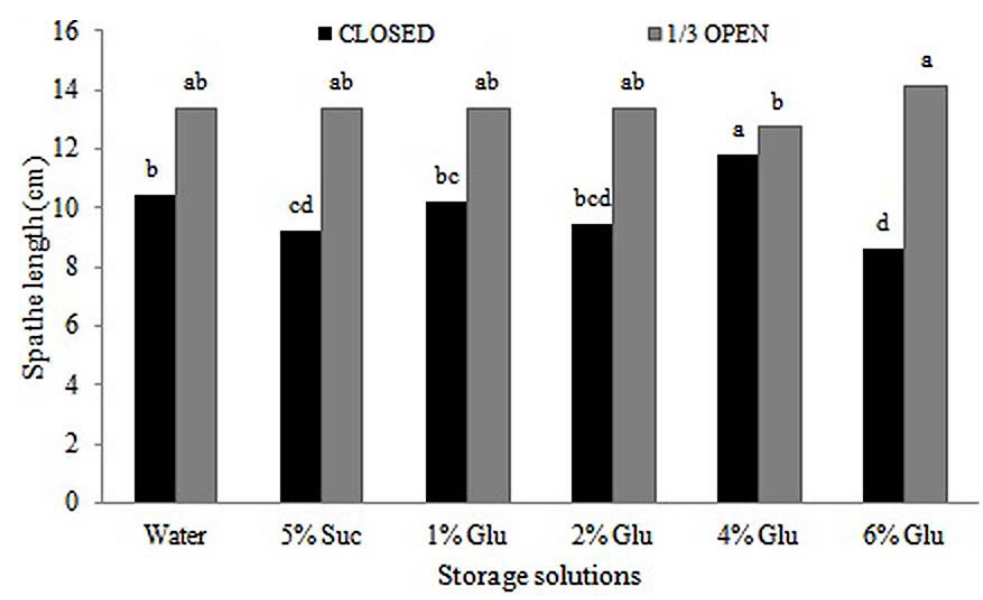

Figure 4: Spathe length of calla lily flower stems as a function of harvest stage and storage solutions. Averages followed by the same letter for harvest stage do not differ by the Tukey test at 5\% probability.

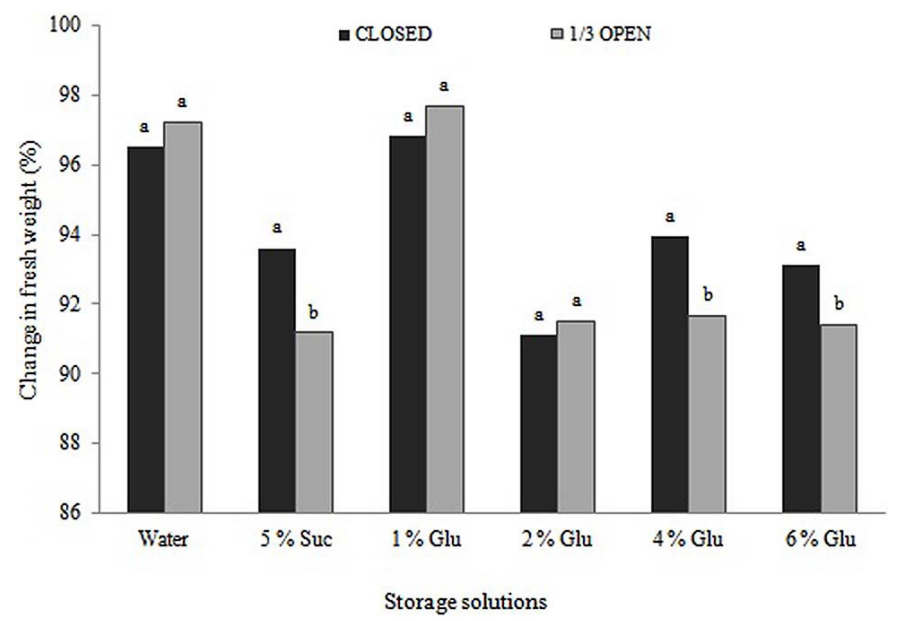

Figure 5: Percentage change in fresh weight of calla lily flower stems as a function of harvest stage and storage solutions. Averages followed by the same letter for storage solution do not differ by the Tukey test at $5 \%$ probability. 

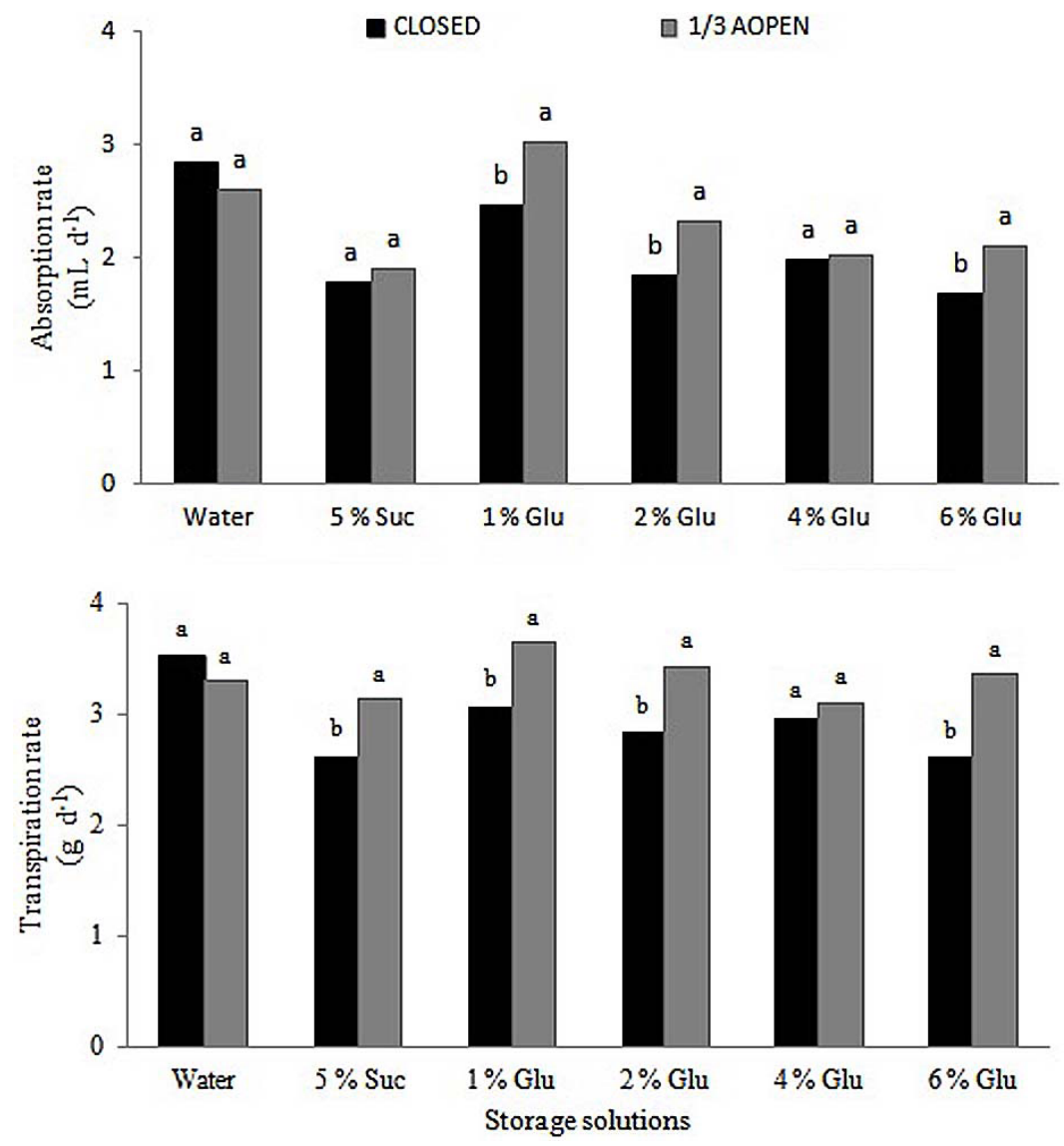

Figure 6: Absorption rate (A) and transpiration rate (B) of calla lily flower stems as a function of harvest stage and storage solution. Averages followed by the same letter for storage solution do not differ by the Tukey test at $5 \%$ probability.

A greater weight loss was observed in stems in solution with sucrose or higher glucose concentrations, indicating that higher sugar concentrations may cause phytotoxicity or trigger physiological processes that lead to senescence. The use of a $1 \%$ glucose solution has also been shown to be beneficial for the maintenance of fresh weight in tulips (Watanabe et al., 2013).

Depending on the amount, the addition of solutes in water reduces water potential and increases the viscosity of the storage solution, which reduces absorption by the stems (Van Doorn, 1996). This effect was observed in solutions with sucrose and glucose at concentrations exceeding $2 \%$. However, with the use of glucose at a concentration of $1 \%$, the effect is similar to the use of pure water, thus confirming the effect of solutes added to water on absorption. In lily inflorescences, there was a reduction in water absorption with increased sucrose concentrations in the pulsing solution (Barbosa et al., 2005). Likewise, transpiration rate was influenced by increased solute concentrations, that is, at higher concentrations of glucose and in the presence of sucrose.

Considering the opening stage, transpiration and absorption rates were higher in harvest $1 / 3$ open, which can be justified by the greater exposure surface and physiological development of the spathe, occurring greater physiological activity (Taiz; Zeiger, 2013).

In all storage solutions and both harvest stages, the transpiration rate exceeded that of absorption (Figure 6), which was evidenced by the fresh weight reduction observed for harvest stages and solutions tested (Figure 5). Solutions with $1 \%$ glucose or pure water enabled a better maintenance of water balance, with smaller stem weight losses.

\section{Biochemistry aspects}

Analyzing the content of starch in calla lily spathes, different levels were observed in relation to harvest stage, storage solutions and days of evaluation after harvest (Figure 7). 


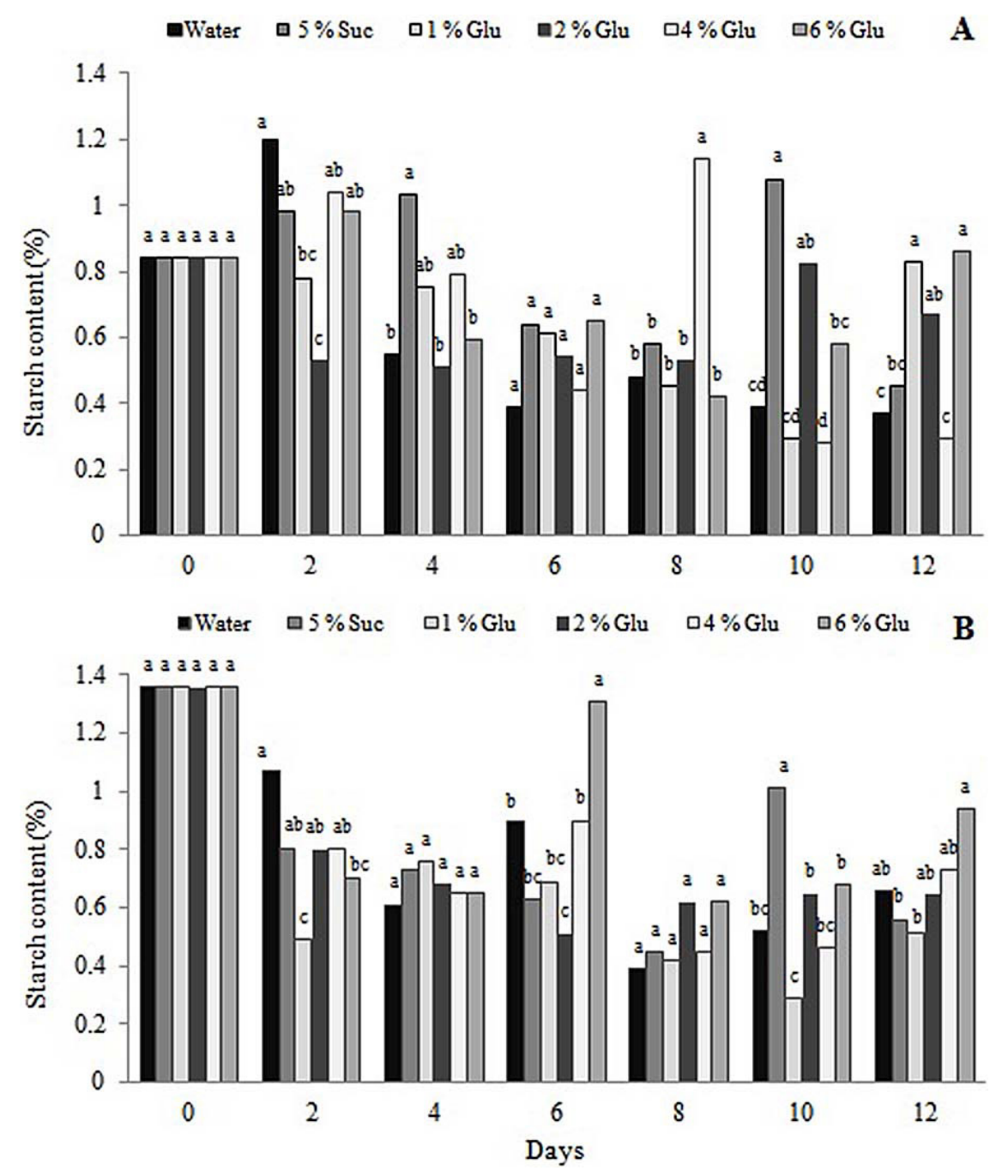

Figure 7: Average starch content in calla lily spathes harvested early(A) and 1/3 open (B) as a function of days of evaluation and storage solutions. Averages followed by the same letter for each day do not differ by the Tukey test at $5 \%$ probability.

Analyzing the content of total soluble sugars in calla lily spathes, they showed differences in relation to harvest stages, storage solutions and days of evaluation after harvest (Figure 8). In the stage 1/3 open, sugar contents are higher in the first days after harvest, tending to reduce over time, especially in stems kept in water or sucrose (Figure 8B). For early-harvest stems, it is not possible to observe this reducing trend, similar to that observed when considering starch content (Figure 7A).

The starch content in the spathe was high during the first days after harvest, followed by a reduction for both stages. This behavior may be related to the fact that stems harvested at early stages have a significant amount of starch and, after full opening; it is readily used as a substrate for respiration.

Similar results were observed in peony flower buds, in which the starch content decreased with storage (Walton et al., 2010). In lily flowers, before full opening, an increase in starch production was also observed, reducing with flower opening (Van Der Meulen-Muisers et al., 2001).

In general, it can be considered that the starch content was higher in stems harvested $1 / 3$ open, compared to early-harvest stages (Figure 7). This greater accumulation can be attributed to the maturation of these stems, which allowed larger storage reserves, effect related to opening stage (Costa; Finger, 2016). 

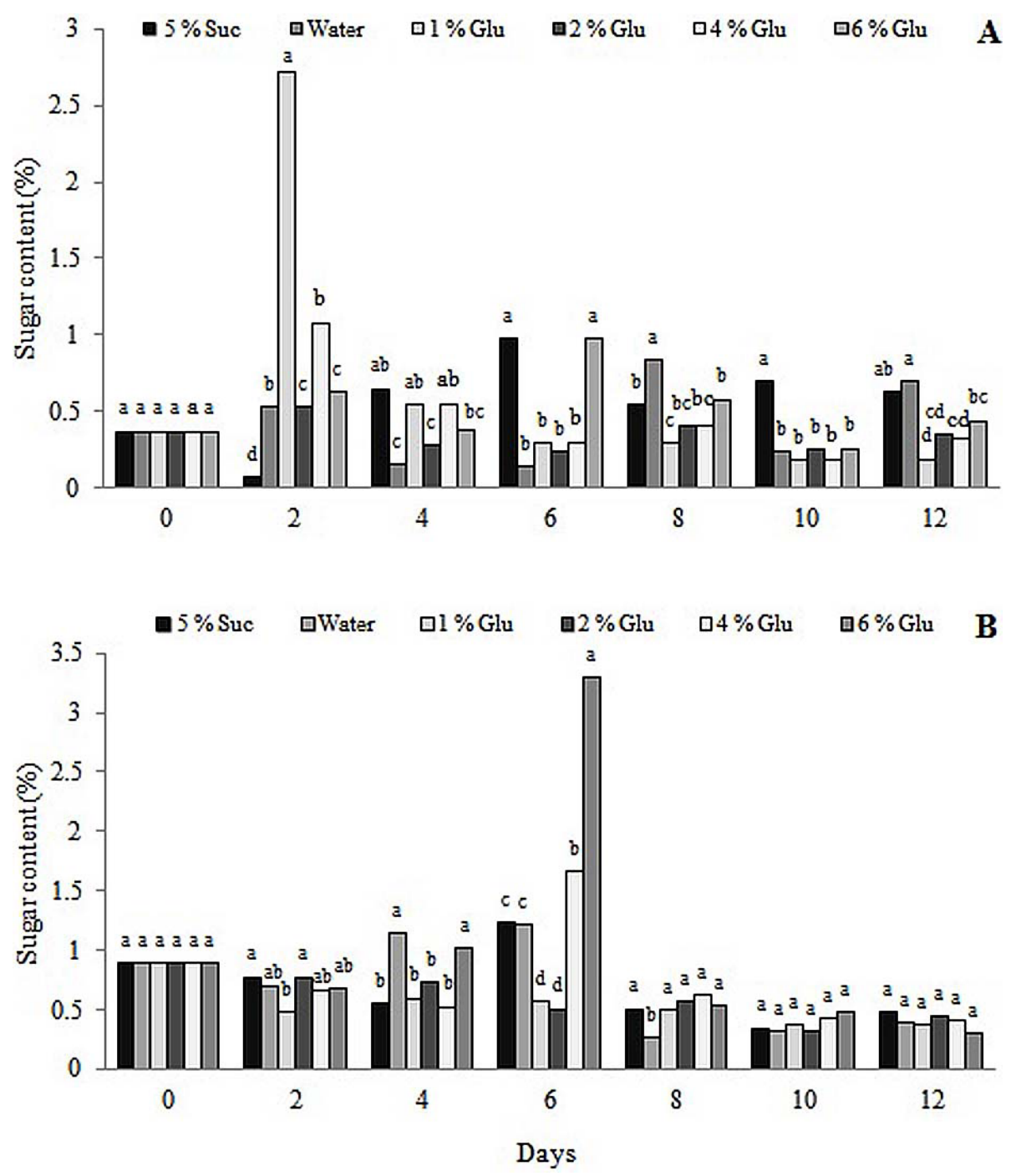

Figure 8: Average contents of total soluble sugars in calla lily spathes early-harvest (A) and 1/3 open (B) as a function of days of evaluation and storage solutions. Averages followed by the same letter for each day do not differ by the Tukey test at $5 \%$ probability.

Starch contents showed some peaks with the senescence process, which can be attributed to the lower activity of the enzyme amylase (Taiz; Zeiger, 2013), or to the fact that there is no need for the degradation of this carbohydrate as a function of sugar supplies in storage solutions. Furthermore, since there is no more cell expansion, this carbohydrate is not degraded and accumulates in senescent inflorescences.

In early-harvest stems, carbohydrate contents were kept higher compared to stage $1 / 3$ open, with increased longevity and quality of flower stems (Table 1). In stage $1 / 3$ open, sugar contents were higher in the first days after harvest, followed by a reduction in these contents from the 8th day after harvest, which suggests the consumption of sugars as a respiratory substrate (Taiz; Zeiger, 2013).

The presence of sugars may have led to a reduction in water potential of spathes, providing water inflow for cell expansion and flower opening. Although in harvestes stems early and $1 / 3$ open did not reach complete spathe opening, their expansion was observed (Figure 3 and 4).

It was observed that the inclusion of sugars (glucose and sucrose) in storage solutions did not increase the concentration of total sugars in the spathe, similar to the effect observed in Dendrobium (Pattaravayo; Ketsa; Van Doorn, 2013). 


\section{CONCLUSIONS}

The addition of sugars to the storage solution was effective in opening early-harvested stems. For both harvest stages, early and 1/3 open, the addition, respectively, of glucose at concentrations of $4 \%$ and $6 \%$, stimulated flower opening. Calla lily flower stems maintained in water and in solution with $1 \%$ glucose had lower percentages of fresh weight loss and better maintenance of water balance. The contents of starch and total soluble sugars in calla lily flower stems kept in water and in solution with $1 \%$ glucose showed a small reduction as a function of days after harvest. Calla lily stems harvested in early stage maintained their commercial quality for a longer time, without the presence of pollen.

\section{ACKNOWLEDGEMENTS}

This work was supported by FAPEMIG (financial support), CNPq (scholarship and financial support) and CAPES (scholarship).

\section{REFERENCES}

ALMEIDA, E. F. A. et al. Pós-colheita de copo-de-leite: Efeito de diferentes conservantes comerciais e armazenamento a frio. Ciência e Agrotecnologia, 32(4):189-1194, 2008.

ALMEIDA, E. F. A. et al. Postharvest aspects of roses. Ornamental Horticulture, 23(2):160-165, 2017.

ALMEIDA, E. F. A. et al. Calla lily inflorescences postharvest: Pulsing with different sucrose concentrations and storage conditions. Ciência e Agrotecnologia, 35(4):657-663, 2011.

BARBOSA, J. G. et al. Longevidade de inflorescências de lírio em função do estádio de desenvolvimento do botão e do condicionamento em sacarose. Bioscience Journal, 21(2):25-31, 2005.

BAYOGAN, E. R. V.; JAROENKIT, T.; PAULL, R. E. Postharvest life of bird-of-paradise inflorescences. Postharvest Biology and Technology, 48(2):259-263, 2008.

BURGE, G. K. et al. Prevention of floret abscission for Agapanthus praecox requires an adequate supply of carbohydrate to the developing florets. South African Journal of Botany, 76(1):30-36, 2010.

CASTRO, M. L. R. et al. Estádio de abertura floral e qualidade pós-colheita em armazenamento de copo-de-leite. Revista Brasileira de Horticultura Ornamental, 20(2):131-136, 2014.
CHO, M. C.; CELIKEL, F.; DODGE, L. Sucrose enhances the postharvest quality of cut flowers of Eustoma grandiflorum (Raf.) Shinn. Acta Horticulturae, (543):305-315, 2001.

COSTA, L. C.; FINGER, F. L. Flower opening and vase life of gladiolus cultivars: The sensitivity to ethylene and the carbohydrate content. Ornamental Horticulture, 22(2):147-153, 2016.

DISCHE, Z. General color reactions. In: WHISTLER, R. L.; WOLFRAN, M. L. (Ed.). Carbohydrates chemistry. New York: Academic, 1962, p.447-512.

GAST, K. L. B. Water quality for florists: Why is it so important. Manhattan: Kansas State University. 2000.

HALEVY, A. H. Treatments to improve water balance of cut flowers. Acta Horticulturae, 64:223-230, 1976.

KAYS, S. J. Postharvest physiology of perishable plant products. New York: An Avi Book, 1991, 532p.

KETSA, S.; BOONROTE, A. Holding solutions for maximizing bud opening and vase-life of Dendrobium 'Youppadeewan' flowers. Journal of Horticultural Science, 65(1):41-47, 1990.

MARISSEN, N. Effects of pre-harvest light intensity and temperature on carbohydrate levels and vase life of cut roses. Acta Horticulturae, 543:331-34, 2001.

MONERUZZAMAN, K. M. et al. Effect of sucrose and kinetin on the quality and vase life of Bougainvillea glabra var. Elizabeth Angus bracts at different temperatures. Australian Journal of Crop Science, 4(7):474-479. 2010.

NELSON, N. A photometric adaptation of the Somogyi method for the determination of glucose. Journal of Biological Chemistry, 153(2):375-380, 1944.

NOWAK, J.; RUDNICKI, R. M. Postharvest handling and storage of cut flowers, florist greens and potted plants. Portland: Timber, 1990, 210p.

NOWAK, J.; GOSZCZYNSKA, M. D.; RUDNICKI, R. M. Storage of cut flowers and ornamental plants: Present status and future prospects. Postharvest News and Information, 2(4):255-260, 1991.

PAIVA, P. D. O.; ALMEIDA, E. F. A. Produção de flores de corte. Lavras: UFLA. 2012, 678p.

PATTARAVAYO, R.; KETSA, S.; VAN DOORN, W. G. Sucrose feeding of cut Dendrobium inflorescences promotes bud opening, inhibits abscission of open flowers, and delays tepal senescence. Postharvest Biology and Technology, 77:7-10, 2013. 
R Development Core Team. R: A language and environment for statistical computing. Vienna: R Foundation for Statistical Computing, 2016

REID, M. S.; JIANG, C. Z. Postharvest biology and technology of cut flowers and potted plants. Horticultural Review, 40:1-54, 2012.

SALES, T. S. et al. Water relations in calla lily flower stems harvested at different opening stages. Ornamental Horticulture, 21(3):368-375, 2015.

SCHMITT, F. et al. Uso de sacarose nas soluções de manutenção de hastes florais de gérberas de corte. Revista Brasileira de Horticultura Ornamental, 19(2):137-144, 2013

TAIZ, L.; ZEIGER, E. Fisiologia vegetal. 5. ed. Porto Alegre: Artmed, 2013, 918p.
VAN DER MEULEN-MUISERS, J. J. M. et al. Postharvest flower development in Asiatic hybrid lilies as related to tepal carbohydrate status. Postharvest Biology and Technology, 21(2):201-211, 2001.

VAN DOORN, W. G. Role of soluble carbohydrates in flower senescence: A survey. Acta Horticulturae, (543):79-183, 2001.

VAN DOORN, W. G. Water relations of cut flowers. Horticultural Review, 18:1-85, 1996.

WALTON, E. F. et al. The dynamics of starch and sugar utilization in cut peony (Paeonia lactiflora Pall.) stems during storage and vase life. Postharvest Biology and Technology, 58(2):142-146, 2010.

WATANABE, Y. et al. Effect of sugar treatments on the vase life of cut tulip (Tulipa gesneriana L.) flowers. Horticultural Research, 12(2):201-207, 2013. 